\title{
Dreams of Communitas
}

\section{Roger Sandall}

Published online: 27 September 2011

(C) Springer Science+Business Media, LLC 2011

\section{O that this too too solid flesh would melt}

Thaw and resolve itself into a dew!

Optimism struggles in this vision of the human prospect, where the restlessly tweeting "children of liberal democracy" are setting the world's teeth on edge. We are reassured that "The Old Adam will have the Last Word." But are his innumerable descendants listening? It is encouraging to learn that in Victor Turner's communitas one may find, however briefly, the peace that passeth understanding, along with fraternity of a kind; but after a friendly nod to Comte's Religion of Humanity it's hardly surprising that at the end of Robin Fox's unique and immensely stimulating book, the author, like the rest of us, ends up worrying about social solidarity, and whether the political structure of civil society is strong enough to hold. His closing ruminations are wide in scope. Perhaps Victor Turner's thoughts on Durkheim, Bergson, and communitas might be a place to begin.

That Turner often had Durkheim's ideas about solidarity at the back of his mind emerges in a discussion of 'Liminality and Communitas' in The Ritual Process (106107). There he lists what he calls "a series of binary oppositions or discriminations" in which the first term denotes an amorphous transitional or "liminal" social state, while the second denotes rank, order, organization, and social structure generally. Twenty-six such oppositions are offered, the following ten being representative pairs:

R. Sandall $(\bowtie)$

98 Hall St.,

Bondi Beach, Australia, NSW 2026

e-mail: rogersandall@bigpond.com

\begin{abstract}
Totality/partiality
Homogeneity/heterogeneity

Communitas/Structure

Equality/inequality

Absence of property/property

Absence of status/status

Absence or rank/distinctions of rank

Humility/pride of position

No distinctions of wealth/distinctions of wealth

Unselfishness/selfishness (Turner 1969: 106)
\end{abstract}

From their tone one feels it might not be too unfair to summarise the first and morally favored terms of the opposition as follows: The homogeneous totality of communitas is an ethically superior human condition where equality, humility, and unselfishness spontaneously prevail. Yet on reading through this list something seems to be missing - something you'd expect to find. Where in this lexicon is the word "solidarity"? Doesn't Durkheim's term and concept plainly belong among these alternatives? Given the drift of Turner's thought - especially when you consider that solidarity is the tribal-communitarian virtue par excellence - shouldn't one expect to see it in there too? And more than that: wouldn't you logically expect to find solidarity on the left side, as the first and honored term, with its dishonoured antonyms aligned on the right, as below?

\section{Solidarity/Inequality, Property, Rank, Wealth, Pride}

But it doesn't appear. And when, eventually-in the following chapter, and not until many pages later-Turner decides that the concept of solidarity should perhaps be part of the argument, his acknowledgment only deepens the 
mystery. Expanding on the communitarian ideals of Martin Buber, and picturing a social model of "homogeneous, unstructured communitas whose boundaries are ideally coterminous with those of the human species", Turner writes that "communitas is in this respect strikingly different from Durkheimian 'solidarity,' the force of which depends on an in-group out-group contrast." (Not just different, but strikingly different.) After this he goes on to add even more problematically that "to some extent", communitas is to solidarity as Henri Bergson's “open morality" is to his "closed morality" (Turner 1969: 132).

We shall return to Bergson. As for Durkheim, one might first note that the passage quoted above provides in a confusing way the missing opposition we were looking for earlier (communitas/solidarity). Yet surprisingly, and against all expectation, solidarity is found on the pejorative side of the division as an anti-communitarian and disfavoured term. Since Durkheim famously invented two forms of solidarity (firstly "mechanical," based on the sameness of social units; secondly "organic", based on the complementarity of disparate social units in what Hayek would call the extended order of human cooperation) it is quite possible that he means the second. But at the same time such an emphasis would seem odd, since everyone already familiar with Durkheim knows this - knows that "organic solidarity" refers to the vast complex of anonymous and invisible interdependencies on which modern social organization rests. Surely the only point of associating Durkheim with communitas would be to bring out the obvious parallel — the very striking parallel in fact — between Turner's notion of absolute homogeneity and Durkheim's concept of "mechanical solidarity" on the other, something the French thinker describes in what are virtually Turner's terms when describing communitas: "If, by a process of thought, we attempt to constitute the ideal type of a society whose cohesion would result exclusively from resemblances, we would have to conceive of it as consisting of an absolutely homogeneous mass whose parts would not be distinguishable from one another... In short, the mass would be devoid of any definite form or articulation" (Durkheim 1984: 126).

Secondly, as to the claim that "Durkheimian 'solidarity'... depends on an in-group out-group contrast," Turner is less than convincing. As usually understood, Durkheimian solidarity concerns internal matters of integration and cohesion. To be sure, it assumes a boundary between sociological exhibits A and B. It may also be conceded that as a group's sense of solidarity grows, so does its awareness of the boundary between "us" and "them." But as a contingent social attribute solidarity is clearly both endogenous, and at the same time largely indifferent to out-groups, whether contrasting, similar, or isomorphic. The empirical entity itself may be as small as a family or as large as an empire. But the solidarity that Durkheim describes in The Division of Labor is exclusively a matter of internal integration. External boundaries are something he takes for granted.

Then there's the allusion to Bergson: "to some extent," writes Turner, communitas is to solidarity as Henri Bergson's "open morality" is to his "closed morality." The phrase "to some extent" warns that the analogy is imperfect. But one has to ask, more radically, does it in fact express what the philosopher really meant? Or has Turner somehow got things back to front? Bergson did make occasional statements that appear to justify the equivalence Turner claims. In Two Sources of Morality and Religion, where he describes the human scene in evolutionary terms as consisting of "closed societies" (the tribal world) or "open societies" (the post-Socratic and Christian world of Western Civilization), he distinguishes "the closed soul" and "the open soul" as follows: "Suppose we say that (the open soul) embraces all humanity: we should not be going too far, we should hardly be going far enough, since its love may extend to animals, to plants, to all nature" (Bergson 1935: 27).

But here he is speaking of the expansive moral universe where "No man is an island entire of itself", a moral universe of rational and independent agents all of whom are nonetheless "A part of the main." Far from being a structureless and somewhat nebulous domain of feeling like communitas, Bergson's "open society" is (to borrow from Jacques Barzun) a House of Intellect-a house of many mansions in which a myriad social and intellectual activities powerfully and creatively interact. A House of Intellect is not the same as a Sea of Feeling. It is the dwelling place of clear thought rather than the excitements of the limbic system. Despite what Turner evidently believed, Bergson's "open society" contains the structural complexity of all the legal constraints, contracts, and civil obligations of the functionally differentiated and multifarious Gesellschaft world, as we must assume Karl Popper understood when he adopted the phrase for the title of The Open Society.

\section{Communitas: A Cuban Example}

In Turner the ideal of communitas seems to embody a dream of escaping the constraints of social structure that closely resembles the utopian dream of political statelessness - the dissolution of social structure paralleling the withering away of the state. All the same, and while a degree of scepticism may be appropriate, there's clearly a mysteriously communal "something" here that many people report experiencing, and that has a number of literary reflections, from Walt Whitman exuberantly adrift on the oceanic currents of the city, to Chekhov's country doctor Dorn, in The Seagull, recalling his enjoyment of Genoa with its evening streets "surging with 
people. You let yourself drift among the crowd... live its life, its soul pours into you, until finally you begin to believe there might really be a 'world spirit' after all..." The Sea of Feeling, with its oceanic sensations soaking up and absorbing all the pains and troubles of the troublesome Family of Man, is surely an experiential reality that should be recognized-however hard it is to describe or explain.

At a practical level, however, what is noticeable is its transience. Its instability. How ephemeral it is, that shining dewy dawn of communitarian unity with its holy trinity of freedom, equality, and fraternity. And how quickly it flips into a harsher state as the revolution's noonday sun beats down. Chemical metaphors come to mind-crystallization for example. One minute there's the sweetly smiling ambience of come one, come all; the next minute men are waving guns.

Something like this happened to me 50 years ago in Havana about 6 months after Castro had taken over. Despite restrictions on visits by US citizens, the New Zealand passport I had at the time enabled me to stop over for $12 \mathrm{~h}$ on a Cubana Airways flight home from Mexico City to New York. The atmosphere was infectiously optimistic (Durkheim's term "effervescent" may belong here). A taxi took me out on a ride along the coast to Miramar where mansions were supposedly being converted into homes for orphans, or into schools or hospitals; and the friendly enthusiasm of the workmen seemed genuine, a feeling that was exhilarating and new-a feeling, moreover, that made you surer than ever that the revolutionary removal of Fulgencio Batista along with the gangsters around Meyer Lansky and Lucky Luciano could only be for the better. That I was visiting the expropriated homes of what may formerly have been honorable law-abiding Cuban citizens living decent lives never crossed my mind. If there was blood on the walls I didn't look for it. I neither knew nor cared whether the previous owners were alive or dead. As Paul Hollander has ably documented, such is the mental world of the political fellow-traveller.

Then later in the day I found myself on the fringes of an assembly of perhaps 10,000 people gathered in a central square. Castro was supposed to speak and a rostrum was ready. I stood there idling a long time, wandering about to break the monotony, waiting perhaps $4 \mathrm{~h}$ for the appearance of el maximo lider. It's true that this was neither the inception of the Cuban Revolution (to locate it among Fox's instances of communitas in daily life) nor the revolution itself. The specific revolutionary phase was visually identifiable by the many ESSO signs that had been eagerly torn down, but that nobody knew what to do with. Jumbled where cars formerly had parked, they showed how much easier it is to wreck than to build - especially in the case of political upheavals.

But it was the mood of the crowd, liminal, liminoid, or whatever, that may be of interest. This being that of men and women passionately sharing egalitarian beliefs and sentiments, eagerly awaiting their charismatic leader, and closely bonded by a spirit of-well, call it communitas. Within this animated collectivity I was at first welcomed as a sympathetic member. But the passing hours brought doubts as to who I was and what I was doing, while my mien as an alien observer became a perceptible matter of concern. At this point a girl of twenty or so wearing military fatigues approached me with a pin and a miniature revolutionary flag, and with a look impossible not to misinterpret, firmly pinned the flag on my shirt.

Doubtless that was to be expected. My suggestion, however, is that the warmly deliquescent, unbounded, we're-all-in-this-together state, the sublime condition recorded by Turner as communitas, and one that might fairly have characterised the emotions of the assembly, quickly crystallized into another where latent structure was abruptly laid bare... Castro, by the way, never turned up. $\mathrm{He}$ sent the Secretary of the Cuban Communist Party instead. And the girl in fatigues with her revolutionary flags turned out to be routinized charisma in its direst form: an official of the One-Party State.

\section{From Ritual to Theatre}

In From Ritual to Theatre Turner reminds us on page 114 that the etymological meaning of "entertainment" is "held-inbetween". In agricultural societies in historic times it was a "liminal or liminoid phenomenon" held in between bouts of plowing, harvesting, eating, house-building, and so on. In the introduction to his book he says that its essays "chart my personal voyage of discovery from traditional anthropological studies of ritual performance to a lively interest in modern theatre, particularly experimental theatre." However, the claimed historical connection between ritual and theatre is not uncontroversial. A severely semiotic work by Eli Rozik, The Roots of Theatre: Rethinking Ritual and other Theories of Origin, (University of Iowa Press, 2002) argues uncompromisingly that "The medium of theatre could not have originated in ritual, since these are ontologically different entities." The claim that they "could not have originated in ritual" sounds a bit extreme, but that they "need not" is surely defensible. As a one-time film-maker who recorded a number of the Australian Aboriginal ceremonies that figure in both Durkheim's and Van Gennep's writings about religion, it may not be inappropriate here for me to simply describe what I saw-suspending judgment and ignoring definitional fuss for the time being: e.g., Is it ritual? Or drama? Or theatre? Or communitas? Or what?

Anyway let's clear the decks. For the sake of evolutionary argument let us agree that story-telling must be as old as language, and that hunting adventures and the haps and mishaps of gathering roots and berries must have been recited 
around camp fires for uncounted millennia. Any storyteller of imagination will "act out" certain scenes to make them more interesting; he at first does this solo before an audience of varying size; and the larger the role of the histrionic the more a division is recognized between the "as is" descriptive world of everyday and the "as if" imaginative world of fiction and myth. We thus have a suite of four elements: story, mimesis, actor and audience, and an emergent awareness that in the "as if" world depicted in drama, which soon goes far beyond describing events to the telling of some very tall tales indeed, everyday reality is not to be expected.

Australia appears to have had a largely isolated huntergatherer population for 40,000 to 50,000 years before European settlement. I suggest that throughout this period the above suite of theatrical elements may well have existed, and that there are no strong reasons for believing it did not. All traditional Aboriginal ceremonies told a story; actors personifying totemic figures acted scenes from the story; the performance space separated them from an audience; this spatial separation might be seen as gradually strengthening a cognitive separation between different orders of human social reality, the "players" belonging to one and the audience to another.

It is true that the roles of such totemic characters as "kangaroo-men" and "emu-men" are conventional and their actions relatively unvarying. We might say there is an element of ritualization. Nevertheless audiences appreciate the predictable action as much as any modern audience appreciates the predictable death of Claudius or the fate of villains in general. The classic ethnography of Spencer and Gillen, The Native Tribes of Central Australia (1899/1968) describes a ceremony in which actors playing a series of sinister "Kurdaitcha men" (or witches) are violently killed by an old man who is their would-be victim. The authors write that:

A mock fight took place in which the Kurdaitcha was always worsted and tumbled down, the old man each time giving him a final tap with his club, which particularly pleased the audience, for in these performances there are certain conventional actions which must be observed by the actors. One after another the Kurdaitcha men came up, and each was worsted in his turn.

When apparently all had been killed the old man still went wandering about, and the same performance was again gone through. After about $15 \mathrm{~min}$ had been spent in this way the old man leisurely walked back to the group of spectators, once more killing each of the men before he got there.

When close to home a combined attack was made upon him, but with no success, as he killed them all and the performance ended with him standing, brandishing his club over their dead bodies, which were heaped together in front of him. The actions of the old man and of the Kurdaitcha men might have been copied from a stage fight. (My emphasis, RS)

In the 1970 film Pintubi Revisit Yaru-Yaru a scene showing a man and boy ambushed at night followed a similar scenario. But were not Aboriginal "increase ceremonies" solemn religious events rather than enactments of violent affrays? In most cases they were - or they were in large part. At these, the Durkheimean boundary between the sacred and the profane was very clear. In the late 1960s our film production team provided transport for the Aboriginal participants, all of them male since women were excluded from such events, back to sacred sites in the desert where the action took place. These were waterholes and rocky outcrops often associated with caves, where totemic spirits dwelled, and they were sometimes many miles from where the men were living at the time. Coming closer, bumping along the dusty desert tracks, we passed both territorially and psychologically from the profane to the sacred, a change signalled conversationally as talk became more constrained, sotto voce, and whispered. Upon our arrival a hush descended, followed by the weeping of men whose failure to visit the site in recent years, because they resided far away, made them feel a guilty regret for neglecting the spirits of their ancestors. (Sandall, see Endnote about films.)

At this introductory stage initiates might be shown the churinga. These long boards carved with totemic designs were described by the Australian anthropologist L. R. Hiatt as "the religious property of one clan... conceived as a tangible relic of the clan's totemic ancestry." (Hiatt 1996: 107) Stored well hidden at normal times in obscure crevices and caves, their recovery and display preceded the main ceremonial action. A dramatic example of this occurs in the film Pintubi Revisit Yumari. At dusk the six-foot tall churinga were held erect by a line of ten men of seniority, while smoke swirled about them from blazing spinifex fires. Young men and juvenile initiates then raced across 100 yards of desert to embrace the totemic relics, while fearsome guttural rumblings rising and falling - the baleful admonitions of neglected spirits?-were flung at the initiates as darkness fell. The intimidating nature of the occasion exemplified the universal teen-taming and team-building aspects of male initiation; in earlier years the grim rite of subincision would probably have accompanied the event.

Now, in terms of Arnold van Gennep's three major stages as set out in The Rites of Passage (separation, transition, incorporation; or séparation, marge, aggrégation in French), the long drive to the sacred site of Yumari in Western Australia involved an unmistakable spatial separation. And by the time the initiates were being frightened into submission by 
the display of totemic relics we were well into the transitional stage. At another site, shown in the film Emu Ritual at Ruguri, the mood of awed respect for the ancestral shrine lasted through a period in which neophytes were introduced to the painted designs on the walls and ceilings of a cave. These designs had been restored by men senior in the hierarchy of sacred knowledge, and men who belonged to one of two moieties (or 'phratries' in Durkheim). Plainly, Turner's "structure" was ever-present. By the same token, however, the communitas-creating music never stopped. It accompanied all ground painting, cave painting, and body painting, along with the building of the wood and hair-string emblems called wanigi; hour after hour its hypnotic and intriguing melody and rhythm served to transport listeners into another realm. Durkheim, drawing on the accounts in Spencer and Gillen's 1899/1968 The Native Tribes of Central Australia, describes how even if the music momentarily stopped and "the singing died away", it would suddenly be taken up again. (Durkheim 1965: 249)

The neurobiological interest of all this may be obvious, as also its relevance to Fox's discussion of "savage rhythms and civilized rhymes" in Chapter Nine of The Tribal Imagination. Likewise the matter of neural disinhibition. From those Aboriginal songs beaten out with a heavy stone on the cave floor at the sacred site of Ruguri, to Gregorian chant, to the contemporary mosh pit with its writhing ecstatics, one can see why Oliver Sacks says "the primary function of music is collective and communal, to bring and bind people together." Truistic, if not trite, the point is nevertheless worth reiterating. He goes on to write that "people sing together and dance together in every culture... and one can imagine them having done so around the first fires, a hundred thousand years ago." In the documentary films I am describing, however, one does not have to imagine it: they vividly show an artistic union of music, dance, and mimetic theatre that appears to be of immense human antiquity. Regarding the collective excitement and social bonding of music Sacks continues: “...there seems to be, in some sense, an actual binding or 'marriage' of nervous systems, a 'neurogamy' (to use a word the early mesmerists favored). The binding is accomplished by rhythm - not only heard but internalized, identically, in all who are present. Rhythm turns listeners into participants, makes listening active and motoric, and synchronizes the brains and minds (and since emotion is always intertwined with music, the 'hearts') of all who participate" (Sacks 2008: 266).

This "synchronizing" of brains and minds may also be thought of as aiding the experiential fusion of past and present where the Aboriginal "Dreamtime" was actualized, its totemic heroes materialized, and they became prepared to enact their legendary travels and adventures once again. Dramatically, we have a story often filled with blood and violence and rapine; we have scenes of action drawn from mythology; we have mimetic impersonations of definite characters; we have allowance made in these impersonations for a degree of individual interpretation. On other matters theatrical, was there during these totemic re-enactments some sort of physical boundary line dividing audience and actors? No: neither a line nor a proscenium. Audience and actors faced each other on level ground. But a clear space marked the performance region of the two or three actors, on the one hand, and the thirty-odd men of the audience/chorus on the other. This loosely corresponded to the contrasting social realities of the "as if" world, where anything is possible, and the "as is" world where men cannot usually fly or travel underground. Next, carrying the emblems of the rite, the men representing the dreamtime heroes moved away to take up their positionspositions perhaps 100 yards distant across the desert.

Then the action began, each actor dancing out from the heat-hazy horizon toward the audience/chorus accompanied by continual cries and exhortation, until, at the climax, his approach brought him close to the others - so near that it was time to return from the Dreamtime to the world of everyday. While it is true that the sacred site was initially treated with hushed respect, it would be wrong to imagine that solemnity always prevailed. In the film Walbiri Ritual at Gunadjari the most eagerly awaited performance involved the totemic hero Wadaingula, a kind of subterranean sexual predator who travelled underground, emerging periodically to rape and pillage, rape evidently being his preferred mode of insemination. The man playing Wadaingula carried before him a six-foot artificial phallus. While he danced, accompanied by prodigious choral uproar and clattering boomerangs, this emblem-it was just a long bundle of straw tied with string-began to detumesce (the Birth of Tragedy perhaps?) to the hilarity of everyone who was there. And a good time was had by all.

So what exactly was this? Ritual? Drama? Comedy or tragedy? Who shall say? Whatever, it was assuredly, as Turner writes commenting on rituals in Central Africa (Turner 1982: 109) "an orchestration of symbolic actions and objects in all the sensory codes-visual, auditory, kinaesthetic, olfactory, gustatory - full of music and dancing and with interludes of play and entertainment." And the fidelity of Durkheim's now 100-year-old account in The Elementary Forms was striking. A dance included in the film Pintubi Revisit Yaru-Yaru shows a snaking line of men, one behind the other, rising from a kneeling position with their hands on each other's waists and swaying from side to side in unison. Here is Durkheim, drawing on Spencer and Gillen: "With fires lighted on all sides, making the whiteness of the gum-trees stand out sharply against the surrounding darkness, the Uluuru knelt down one behind the other beside the mound, then rising from the ground they went around it, with a movement in unison, their two hands resting upon 
their thighs, then a little farther on they knelt down again, and so on. At the same time they swayed their bodies, now to the right and now to the left, while uttering at each movement a piercing cry, a veritable yell, "Yrrsh! Yrrsh! Yrrsh!" ... One can readily conceive how, when arrived at this state of exaltation, a man does not recognize himself any longer... Feeling himself dominated and carried away by some sort of an external power which makes him think and act differently than in normal times, he naturally has the impression that he is no longer himself" (Durkheim 1965: 249).

And of course the dancer "is not himself." Or not his hunting/killing/eating material self. For the duration of the dance he dwells in the imaginary "as if" world of myths and totems along with Wadaingula and kindred spirits. Whilst there his condition is transformed, exalted, liminal, betwixt and between. The dance recorded by Spencer and Gillen was performed among the Warramunga. The territory of the Pintubi tribe whose ceremonies we filmed was further west, and the Pintubi dance ended less boisterously than the Warramunga version as I recall. At the finale the line of men were kneeling down again, their heads lowered and their bodies locked closely behind each other.

Silently, dust hanging in the windless air, an elder who might well be called a master of ceremonies, acting with priestly deliberation and gesturing with the delicacy of someone awaking sleepers from a dream, went slowly down the line touching each man in turn. Released from the world of the Dreaming, they rose to resume their ordinary lives. Subdued conversation began again. Had Durkheim been able to see this action first-hand he would have been pleased to note that each man in the line formed an identical segment like the parts of a centipede - the very model of mechanical solidarity. And, indeed, much more than that. Central Australian increase ceremonies, held annually, were intended to encourage the growth and proliferation of animals and vegetation, and of the fertility of the totemically associated clans. As such, the theory behind them, enlarged on in a broadly religious context by Van Gennep at the conclusion of his book, is "a cosmic conception that relates the stages of human existence to those of plant and animal life and, by a sort of pre-scientific divination, joins them to the great rhythms of the universe" (Van Gennep 1960: 194).

\section{Note re: Documentary Films}

The various ethnographic documentary films mentioned in the text were all produced between 1967 and 1972 by the Australian Institute of Aboriginal Studies (now the Australian Institute of Aboriginal and Torres Straits Islander Studies).
They have not been publicly seen for 40 years, and I am reliably informed that insuperable obstacles prevent their research use. The reasons are various. Firstly, in the early 1970s the elders of the communities concerned were anxious to preserve the secrecy of the rites. Secondly, the matter of exclusivity became an exploitable issue for various Indigenous political interests.

Thirdly, however, it must be recognized that nudity, the copious blood-letting some ceremonial activities entailed (human blood from opened arm veins was spilled on various sacra, was spurted as an elixir into the mouths of elderly participants, and was also widely used as a fixative for building emblems), along with the overtly sexual nature of some scenes, all made such records discomfiting for those who want a sanitized version of the Australian Aboriginal past, and who find such records embarrassing. One of the Institute's main responsibilities is archival. At some point the films were transferred from $16 \mathrm{~mm}$ film to either VHS or Betacam. It is important that they should now be preserved in a safe and enduring digital form such as AVI. A recent enquiry received a belated assurance that after a delay of two decades this task has been "prioritized" and will soon be under way.

\section{Further Reading}

Bergson, H. 1935. Two sources of morality and religion. London: Macmillan [Original French edition 1932].

Durkheim, E. 1965. The elementary forms of the religious life. New York: Free Press [Original French edition 1912].

Durkheim, E. 1984. The division of labour in society. London: Macmillan [Original French edition 1893].

Fox, R. 2011. The tribal imagination. Cambridge: Harvard.

Hiatt, L. R. 1996. Arguments about aborigines. UK: Cambridge University Press.

Rozik, E. 2002. The roots of theatre: Rethinking ritual and other theories of origin. Iowa City: University of Iowa Press.

Sacks, O. 2008. Musicophilia. New York: Vintage.

Sandall, R. Documentary films. Pintubi Revisit Yaru-Yaru, Pintubi Revisit Yumari, Emu Ritual at Ruguri, Walbiri Ritual at Gunadjari, The Mulga Seed Ceremony. All films directed by Roger Sandall and produced by the Australian Institute of Aboriginal and Torres Straits Islander Studies, Canberra.

Spencer, B., \& Gillen, F. J. 1968. The native tribes of central Australia. New York: Dover 1899/1968.

Turner, V. 1969. The ritual process. Chicago: Aldine.

Turner, V. 1982. From ritual to theatre. New York: PAJ Publications.

Van Gennep, A. 1960. The rites of passage. London: Routledge and Kegan Paul [Originally published 1909].

Roger Sandall author of The Culture Cult, lives in Australia. His website can be found at rogersandall.com. 